\title{
Artillery barriers built by the Catholic Monarchs in the Granada coastal fortifications: the Castles of Almuñecar and Salobreña
} Antonio Orihuela Uzal ${ }^{\mathrm{a}}$, Antonio Almagro Gorbea ${ }^{\mathrm{b}}$

School of Arabic Studies, CSIC (Spanish National Research Council). Granada, Spain, aorihuela@eea.csic.es, baalmagro@eea.csic.es

\begin{abstract}
In 1489, after the surrender of the coastal towns of Almuñecar and Salobreña during the Granada War (1482-1492), the Catholic Monarchs immediately set about repairing and improving the military defences of the castles situated in both towns. Due to the important efficiency displayed by the pyroballistic artillery during that war in order to attack and seize the fortresses and towns of the Nasrid Kingdom, the old Andalusi walls were unable to withstand the attacks, therefore the monarchs, together with the captains of their artillery immediately began to adapt the fortifications that had been conquered to make a stand against the new weapons. Basically this led to the construction of artillery barriers based on the experience of those fortresses constructed or adapted during the $15^{\text {th }}$ century in Castile. Particular reference was taken from the important construction of the Castle of la Mota in Medina del Campo. In this article there will be a study of the features of the artillery barriers built in both fortresses.
\end{abstract}

Keywords: Artillery barriers, moats, re-adaptation, Catholic Monarchs.

\section{Introduction}

The two main coastal towns nearest to the capital of the Nasrid Kingdom, Almuñecar and Salobreña, both had defence fortresses on the highest points of the rocky headlands where they are situated. Both fortifications complied with the suitable siege warfare concepts used in medieval times, with stretches of walls and towers constructed with rammed earth, further reinforced at a later date with masonry cladding.

In order to strengthen the capacity for defence, and particularly to adapt the fortresses for the use and protection against the artillery, in both castles artillery barriers were raised. Their main features were the special thickness, low height and loop holes for the use of pyro-ballistic weapons.

The proposal was that these barriers should be protected in part of their height from external attacks by means of deep excavated moats and they were reconnoitred by loop holes and cannon embrasures, situated outside the reach of the attacking artillery, hence guaranteeing the ultimate defence of the fortress, even though the more elevated parts had received hard punishment from the enemy.

Nevertheless, this theory of fortification was adapted to the reality of each case, particularly topographically speaking, giving place to diverse solutions. While in Almuñecar a barrier was constructed giving additional volume to the Andalusi (from al-Andalus times) wall, as well as the excavation of a deep moat, the hard quality of the rock forming the base of the castle in Salobreña made it impossible to carry out a similar defence system. Therefore they recurred to the construction of a double barrier like a defence system in depth, hence offering adequate protection to the castle. 


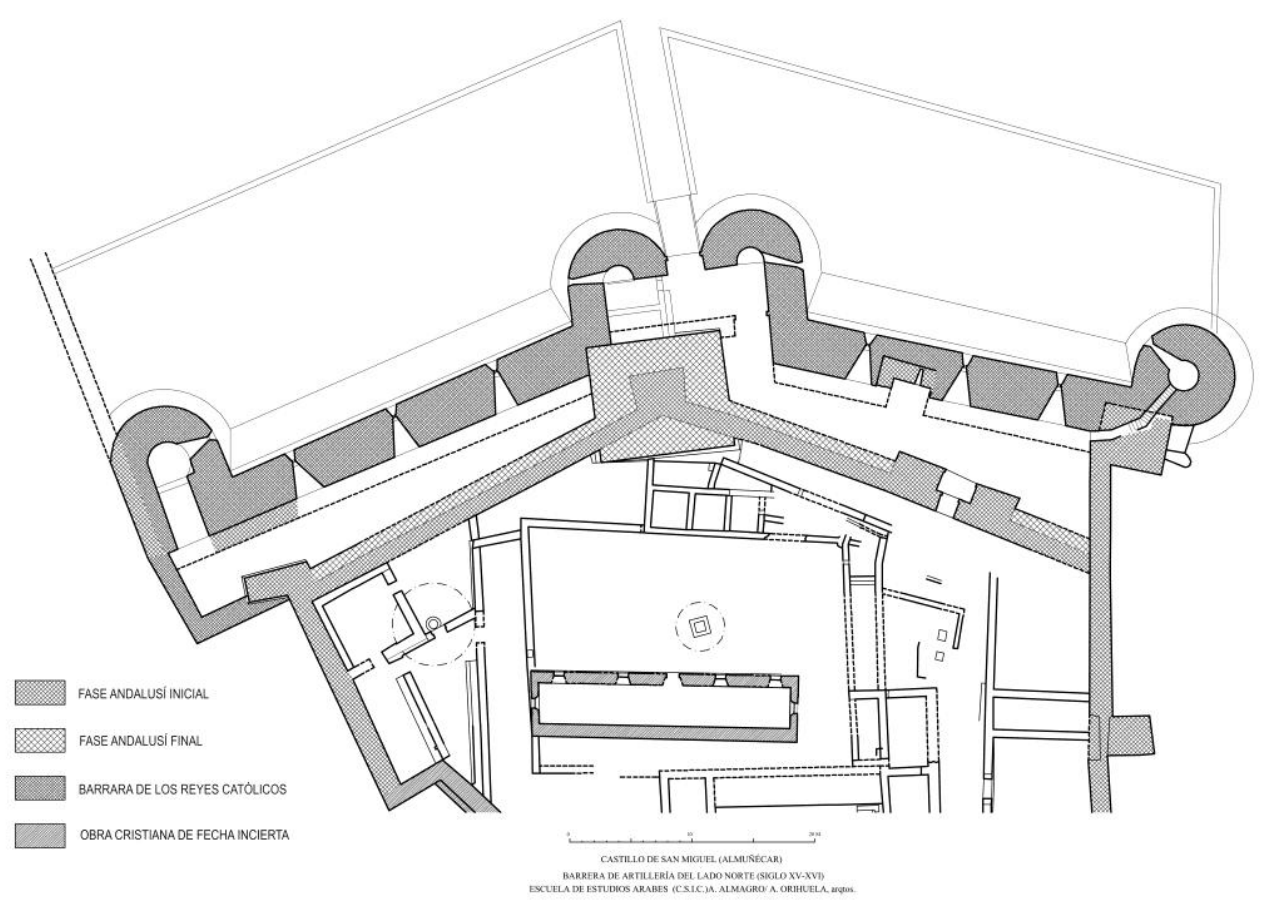

Fig. 1- Ground plan of the northern part of the castle of Almuñecar with its artillery barrier

\section{Almuñecar Castle}

The town of Almuñecar is situated on a hill beside the sea in the middle of the plain formed by the mouth of the Río Verde. On the southern side of the hill, it narrows with the edges of the slopes becoming steeper and therefore they were used for the construction of a fortress, undoubtedly dating from Punic and Roman times. The medieval Andalusi castle had rammed earth walls and solid towers. The northern side, facing towards the town and having easier access, had two stretches of wall which formed a pointed position, with a tower at the vertex. This wall was reinforced during the final part of the Nasrid period with a thicker layer of masonry, which has a particularly significant thickness, surrounding the central tower. In fact it became the most outstanding and powerful element of the fortress. This northern front also had outer walls that surrounded the main walls with some remaining parts that are embedded or attached to the barrier constructed later on.
In 1489, after the surrender of the town to the Castilian forces, the Catholic Monarchs. immediately set about the conditioning and reinforcement of the fortress, which they considered an essential element for the defence of the new frontier of their territories now established further to the conquest of the Nasrid Kingdom on the Mediterranean coast. The experience of the Castilian siege warfare, updated with what they learnt in the Granada War (1482-1492), allowed the fortress to be equipped with the appropriate measures to confront the new weapons.

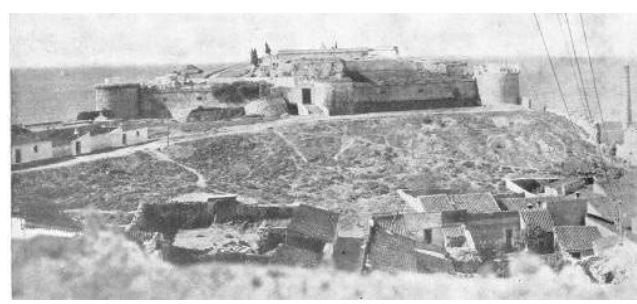

Fig. 2- View of the northern front of Almuñecar Castle in a photo from the first half of the 20th century (L. Torres Balbás) 
Therefore the northern front was strengthened with an artillery barrier, i.e. with a very thick wall $(4,10 \mathrm{~m})$, as it was a more fitting place for attacking the castle, It had round towers at the angles and a moat of almost eight metres in depth, and twenty in width, excavated in the schistose rock of the hill. The two stretches forming the barrier follow directions that are noticeably parallel to those of the previous wall, marked out by the defence wall to which many parts of the new wall were attached. They have a very steep escarpment so the vertical part of the wall scarcely represents a third of the total height with respect to the bottom of the moat.

Of the outermost towers, the eastern one has a circular ground plan and is adjacent to a previous square one. The western one has a semicircular ground plan, extended with straight sides to offer a greater projection over the moat. The main access to the precincts, that was in this northern side, was included into a prominent part formed by two half round towers that flanked the gateway. It had the shape of a low arch, similar to that of the bastion of the Arrabal Gateway in the Alhambra, and similarly we can suppose it was crowned with the royal coat of arms. During the Spanish War of Independence (1808-1814) the demolition of one of the half towers resulted in almost the whole gateway and its top disappearing.

In order to cross the moat a bridge was built, principally of masonry, but with a drawbridge on the side nearest the gateway. This structure was designed to serve as a caponier by which the moat could be reconnoitred better. So the first opening with a round arch had an elevated platform with regard to the bottom of the moat, closed with parapet and battlements and with openings for weapons. The central pier of the bridge has a small room inside with loopholes on both fronts, and it could be accessed by a ladder from a doorway opened towards the moat in the direction of the fortress. This could be accessed descending with a ladder from the main doorway of the castle. This is a simplified version of the one previously used in the Castle of la Mota at Medina del Campo. Each of the stretches of wall is provided with three openings for weapons situated slightly above the line where the escarpment ends and where the vertical wall begins. They have a small trumpet-shape outwards and another much larger one inwards that makes up the firing room.
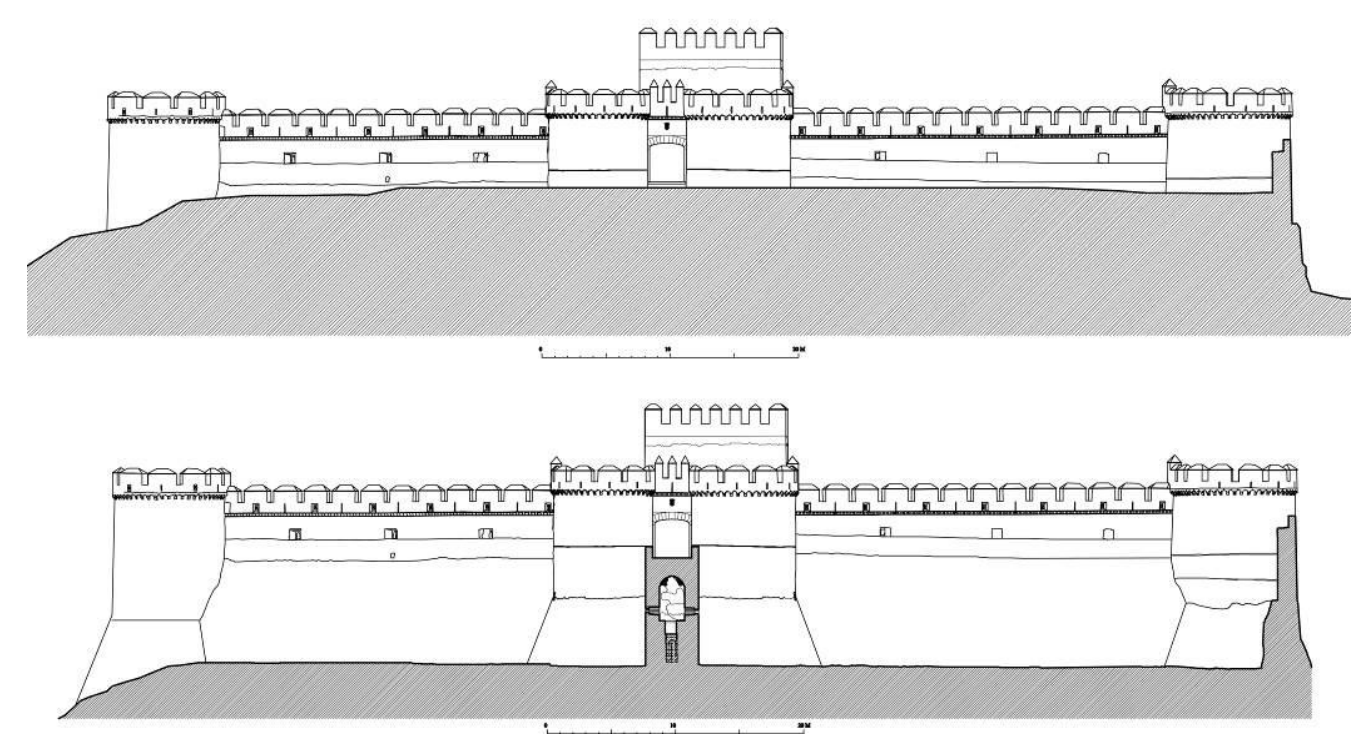

Fig. 3- Front view of the artillery barrier of the Castle of Almuñecar from a distance (above) and from the moat (below) (Almagro and Orihuela, 2015) 

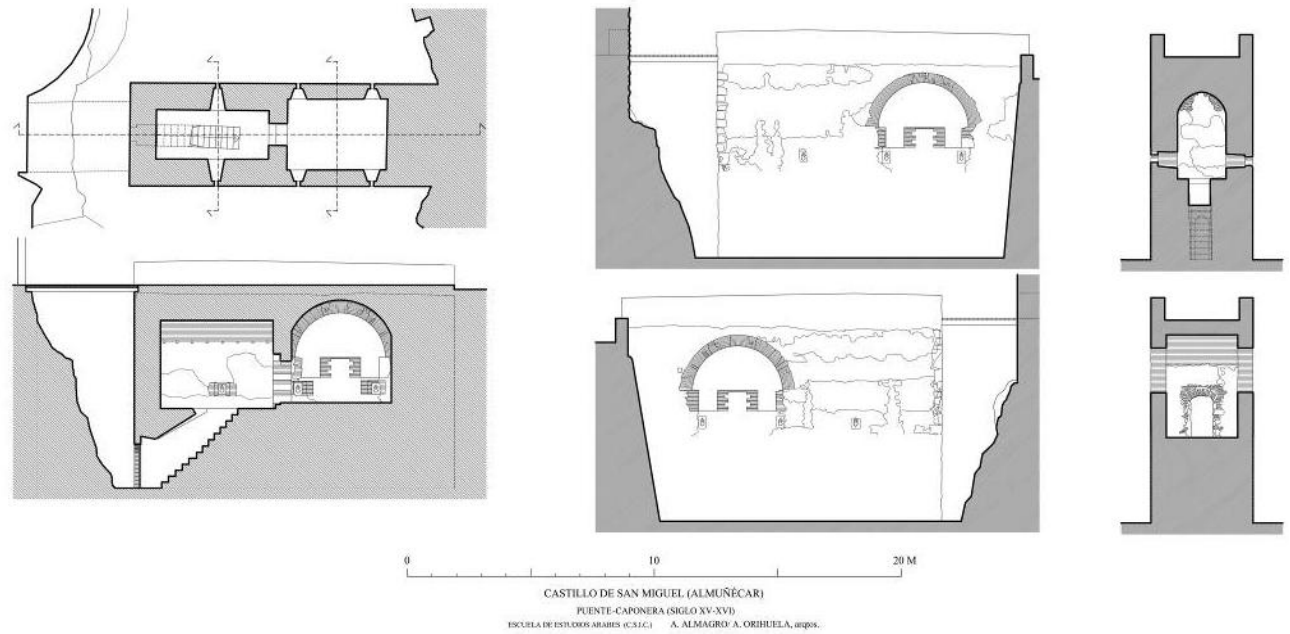

Fig. 4- Bridge-caponier of the Castle of Almuñécar

The walls are topped with a small projection of ogee arches on corbels that support the parapet, that alternate between embrasures and loop holes coinciding with the centre of each battlement. They have a substantial width, similar to other contemporary ones such as those drawn by Francisco de Holanda in the fortress of Salsas. The round towers at the end of the stretches of wall as well as the semi-towers protecting the doorway have small vaulted rooms at a level below the original ground level, provided with loopholes to reconnoitre the bottom of the moat. As they were below the edge of the counterscarp, they were protected from the shots of the attackers, unless they were made from that same edge (Almagro and Orihuela, 2008).

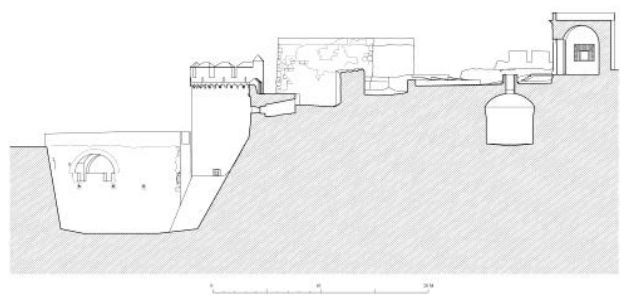

Fig. 5- Cross-section of the barrier and moat of the Castle of Almuñecar (Almagro and Orihuela, 2015).

As can be seen in the cross-section, the part of the walls that is elevated with regard to the terrain, besides being of a great thickness, is hardly elevated in a distant vision, which means that it is barely vulnerable to enemy attack. Following this criterion, the towers are hardly elevated with regard to the stretches of wall. There is full continuity in its parapet walks, which could be crossed along their whole length without any hindrance or impediment. Basically the work was carried out in stone masonry, held in place with excellent lime mortar which was especially hard and resistant. Brick was used in specific sectors such as the jambs of the loop holes and the arches and carved stonework in the arch of the doorway and in the little arches and corbels that mark out the starting point of the parapet.

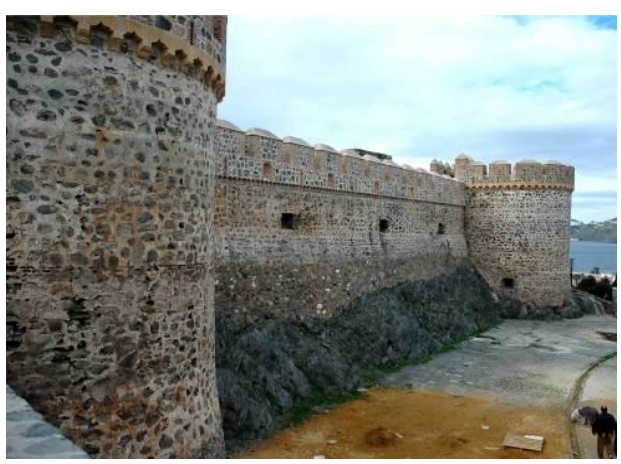

Fig. 6- Western stretch of the barrier of the Castle of Almuñecar. The original escarpment which no longer exists covered the rock that can now be observed. 


\section{Salobreña Castle}

The hill where the Castle is situated has been a human settlement at least since the Punic colonization. There are scarce and decontextualized layers of Punic and Roman remains, Islamic structures of different periods and important fortification works carried out after the surrender of the town to the Catholic Monarchs in December of 1489. Apart from this, there were other later interventions during more than three and a half centuries of military presence and usage.

Since the $10^{\text {th }}$ century Arab geographers began to mention Salobreña. Ahmad al-Razi $\left(10^{\text {th }}\right.$ century) quoted it as a castle, 'Arib b. Sa'id ( $10^{\text {th }}$ century) recognizes it as a town (madina) due to the campaign carried out by 'Abd al-Rahman III in the Cora de Elvira against the Muladí uprising in 913 (Castilla, 1992: 126). Al-'Udri $\left(11^{\text {th }}\right.$ century) referred to it as the administrative area (iqlim) of Salubiniya, while Yaqut $\left(13^{\text {th }}\right.$ century) designated it as a fortification (hisn). Possibly it may have been considered as a fortification between the $10^{\text {th }}$ and $12^{\text {th }}$ centuries, although some historical sources refer to it as a town and others as a farmstead (alquería). Since the Nasrid Kingdom was constituted, there is a greater agreement in regarding it as a town, Salubiniya, in sources of that time. It had city walls, a harbour, a mosque and a citadel (alcazaba) in the highest part, where there was a Nasrid residence used by members of the dynasty as a place of rest and also as a royal prison (Navas and Garcia-Consuegra, 2009).

The transformations undergone by the fortification both in the period of the Catholic Monarchs and Charles V, and throughout the $18^{\text {th }}$ century were so extensive that the facings of the towers and walls that could undoubtedly be attributed to the al-Andalus period only represent a minimal part of what exists at present. The conquest by Castile meant that the citadel was adapted to new types of military architecture demanding a widespread use of artillery. The strengthening of old medieval structures was no longer sufficient, rather than that, methods were needed implying the transition towards Modern Age fortifications. The first governor was Francisco Ramirez de Madrid (died in 1501); he was secretary and field marshal of the artillery between 1482 and 1493. The master commander Ramiro Lopez (died in 1505), main artilleryman and engineer, was commissioned with the fortifications of the Kingdom of Granada after its conquest. He carried out important work in Granada and the Alhambra, Almeria, Almuñecar and Salobreña (Cámara, 2002: 123-137). In the General Archive of Simancas we can find the record of the Statement of work necessary in the aforesaid fortress, dated $17^{\text {th }}$ February, 1490 (Vilar, 2007: 673-676). Although it is difficult to give a precise interpretation of the content of the document, we shall proceed to summarize the main interventions instructed for the improvement of its defensive nature:

- Make an artillery barrier of 130 paces in length towards the southeast, where the town was situated, because this area was the most vulnerable one. It should have three very strong round turrets, one in each part and another in the middle, as it was impossible to excavate a moat around the barrier due to the hardness of the rock of this hill.

- Change the Gateway of the fortress to the far north of the barrier, next to the water tower, being a safer place and easier to defend.

- Build a new tower of Homage next to the Gateway, on top of the foundations of the older existing one. It would be possible for the governor to control all 3 gates from this tower, due to its situation at the highest point of the fortress: the Town gate, the False gate giving towards the country and the Aid gate giving towards the sea.

- Construct a cistern with a capacity of 10.000 pitchers of water, on the site indicated by master Ramiro, being the lowest in the fortress.

- Make a piece of coracha or double wall under the gateway of the Aid from the sea, 100 paces long and with a bulwark at the end of the sea way which approaches 100 paces to the sea, to aid and defend those who came to assist the 


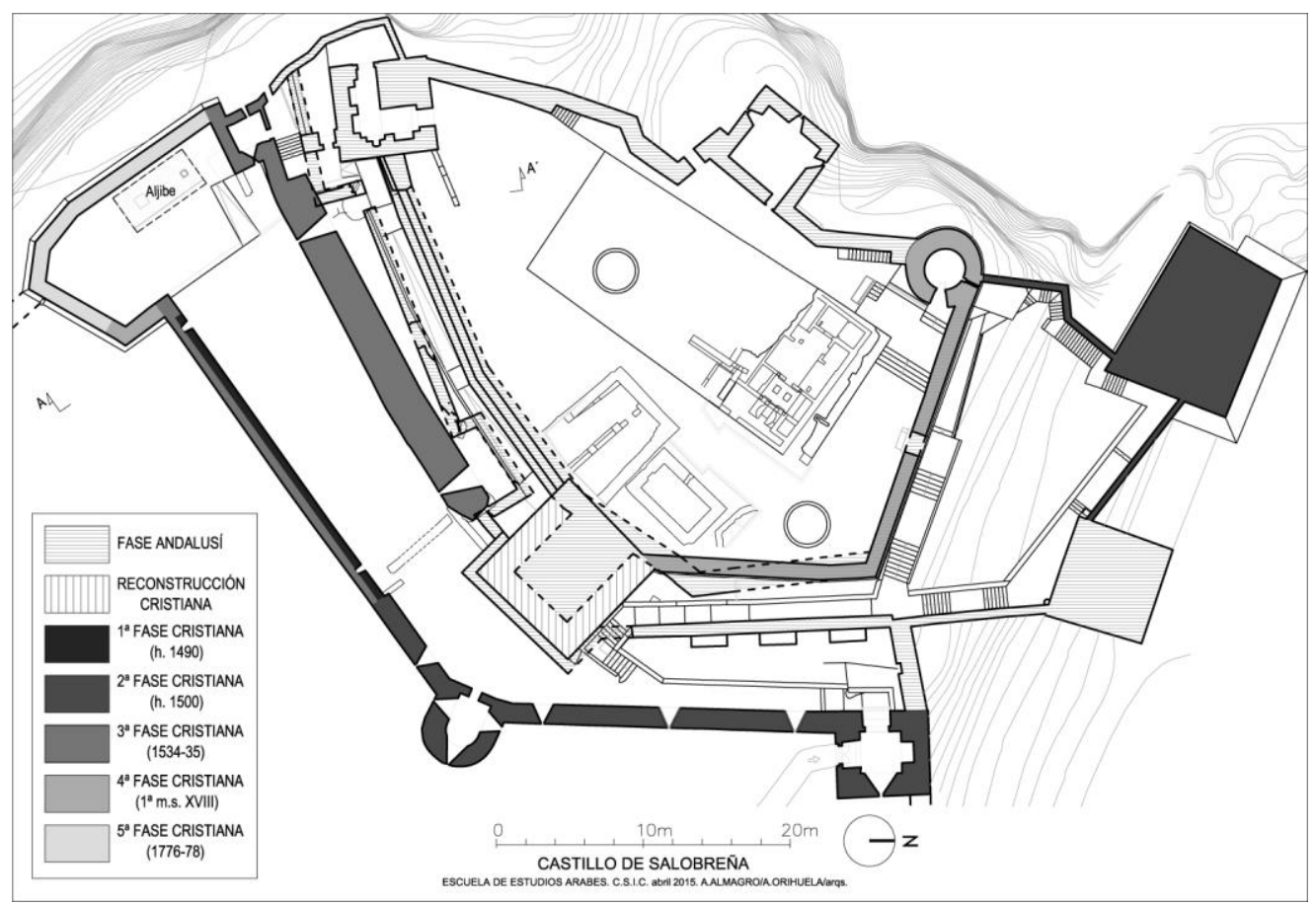

Fig. 7- Ground plan of Salobreña Castle with artillery barriers (Orihuela and Almagro, 2015).

fortress by sea. As it was such a long distance it would [not] be possible to go forward and assist without doing this, because there are 480 paces from the doorway to the sea The majority of the works planned in 1490 were carried out, although they may have been over different stages of construction covering several decades. The most significant one was the construction of an artillery barrier in front of the Islamic walls on the south-eastern side with less steep slopes, with a round turret in the centre.

In the northernmost part of the barrier a new entrance gateway to the precincts from the town was built. On the other hand, in the north-east part of the fortress a coracha or low enclosure was made to protect their access to the sea, with an artillery bulwark orientated towards the port of La Caleta. These precincts also integrated the water tower that since the al-Andalus period had protected the access to a well of a waterwheel which was probably connected via an underground conduction to the medieval irrigation canal that reached the town from the northern area. The work was done with ordinary masonry or strengthened with edges and courses of brick in some parts. The vaults of the towers, rooms and loop holes were also built with brickwork.

The majority of the work planned by Ramiro Lopez had not yet been carried out when there was an earthquake on $26^{\text {th }}$ January, 1494 . The epicentre was in the sea to the southeast of Malaga, and it resulted in the fall of a tower in the Salobreña fortress, together with the collapse of the Tower of Homage (Olivera, 1995:51).

Another important document that gives us information on the proceedings during that decade is the payment accounts corresponding to the building work carried out between August 1496 and December 1498 (Romero, 1995: 117141). In these accounts the construction of the cistern in the southernmost point of the fortress planned by Ramiro Lopez is detailed. Together with this there are details of the reconstruction of the higher part of the Tower of Homage (named New Tower, Rosal or Rosario Tower in the 
document) done on top of the lower part from alAndalus times.

We have further relevant evidence from the Marquis of Mondejar, who visited the fortress on $29^{\text {th }}$ September, 1534 (A.G.S.; C ${ }^{\mathrm{a}}$ del Sueldo; $2^{\mathrm{a}}$ Serie, Leg. 368, Fol. 442-443) to arrange for the restoration and necessary supplies. In this visit he proposed reinforcing with masonry the section of barrier situated between the round turret and the "torrejón" of the cistern. In this way the height could be raised making a parapet and battlements of that material, and pulling down the crenellations made out of rammed earth, in accordance with what had been done in the northern sector of the barrier.

The customary system of parapet-counterscarpmoat-escarpment and artillery barrier used in the fortifications of the transition up to the Modern Age during the reign of the Catholic Monarchs (1474-1504-1516) could not be used in Salobreña. The rock of the promontory where the castle and the ancient medieval walled town are situated, is formed by a carbonated series consisting of calcareous and occasionally dolomitic marble of great hardness. For this reason an artillery barrier was created, relatively separated from the medieval precincts and the foremost wall was maintained. Subsequently, the south-eastern part of it was replaced by a second barrier almost twice as thick as the outer one. However, the only two frontal embrasures extend to a very small surface area between the barriers, and also they are orientated against the first barrier. This was originally of lime-crusted rammed earth (tapia calicostrada), but after 1534 it was covered externally and above with masonry, and the crenellated part was built with the same structure. The work done in the $18^{\text {th }}$ century established a bulwark orientated towards the sea, adapted to the cistern of the end of the $15^{\text {th }}$ century. Later, according to a project by $\mathrm{J}$. Crame in 1767, the bulwark was modified to adapt it to fire in all directions, lowering the height of its parapet.

During the restoration work on the fortress, commonly known as the castle, carried out between 1955 and 1975 under the direction of the architect Francisco Prieto-Moreno, a lot of debris was removed, but excavations following archaeological methodology were not performed. On the contrary, in the intervention that began in 2014 under the direction of the authors of this paper, extensive archaeological excavations were fulfilled, by Dr. Julio Navarro Palazón (EEA-CSIC), together with Antonio Reyes Martínez. Thanks to these excavations it has been possible to open all the embrasures of the two barriers which had been blocked up and in some cases half buried. It has been possible to discover to a partial extent the primitive barrier of rammed earth from the south-east sector; this had been enlarged with masonry after 1534 .

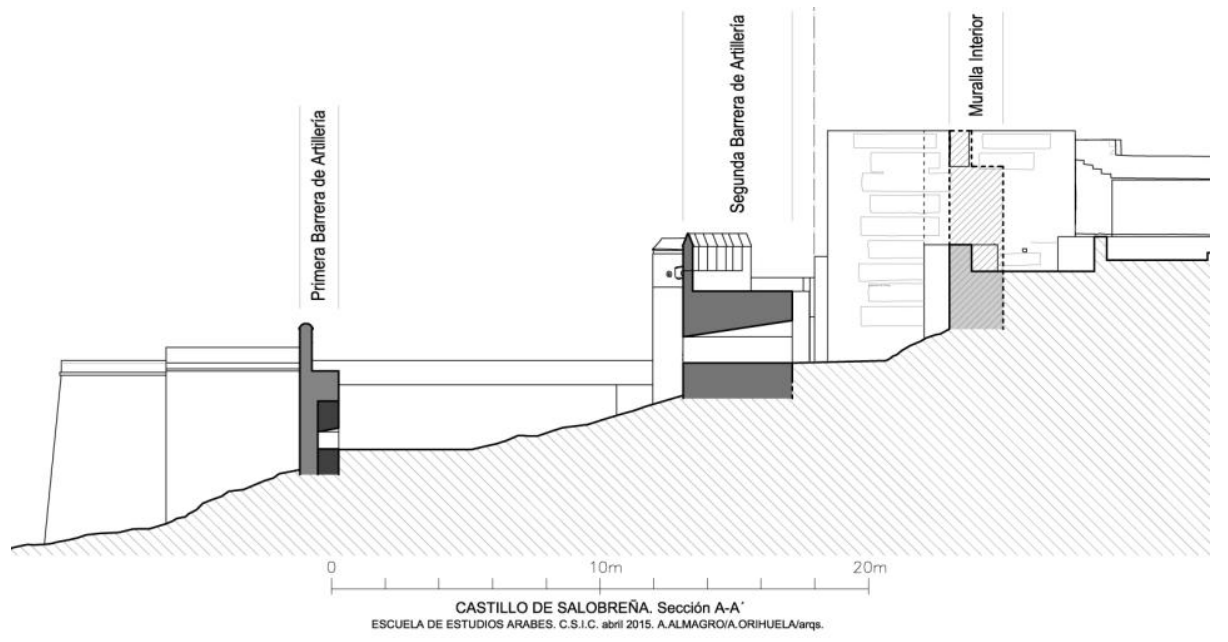

Fig. 8- Cross-section of the artillery barriers of Salobreña castle (Orihuela and Almagro, 2015). 
However, the greatest contribution regarding the defensive system has been the appearance of the lower part of the foremost Andalusi wall, which was amortized when the second powerful barrier was built, to protect the entrance into the interior enclosure of the ancient Nasrid fortress.

When the small houses built up against the outer side of the barrier in the last century can be pulled down, this will recover its former spectacular appearance.

\section{Conclusions}

In the two fortified coastal towns nearest to the ancient Nasrid capital, the Catholic Monarchs decreed the construction of artillery barriers orientated towards the urban area, where their citadels were most vulnerable. In Almuñecar the schistose rock allowed a deep moat to be excavated, following a traditional layout already experienced, with an original bridge-caponier protecting the crossing. However, in Salobreña the intensely hard marble rock prevented an artificial moat from being made, so an artillery barrier was built with a gateway with bends inside a strong tower situated at the opposite end to the entrance into the Nasrid precincts. Therefore the attackers would have to cross the whole area of conflict lengthwise, finding the second part of the route protected by another powerful barrier that replaced the medieval foremost wall.

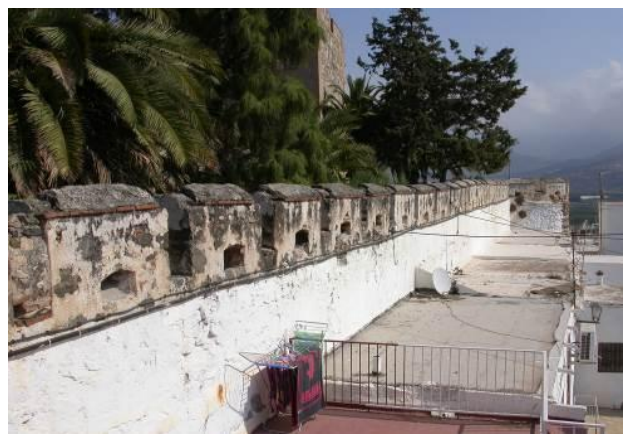

Fig. 9. View of the first barrier and the round Turret in the background, from the Bulwark of the Cistern, with the small houses attached to the outer part.

\section{Referencias}

Almagro, A. y A. Orihuela, (2008), . "Investigación histórica sobre el Castillo de San Miguel de Almuñécar (Granada)", Actas del $4^{\circ}$ Congreso Internacional sobre Fortificaciones: Las Fortificaciones y el mar, Ayuntamiento de Alcalá de Guadaíra, Sevilla, pp. 109-118.

Cámara, A. (2002), "Las fortificaciones del emperador Carlos V" en Carlos V. Las armas y las letras, Granada.

Castilla Brazales, J. (1992), La crónica de 'Arib sobre al-Andalus, Granada.

García-Consuegra Flores, J. Mª (2007), a: "El castillo de Salobreña en época medieval”, Memoria del Diploma de Estudios Avanzados (D.E.A.), dentro del Programa de Doctorado "Arqueología y Territorio" de la Universidad de Granada, Inédito.

García-Consuegra Flores, J. Ma . (2007), b: "El castillo de Salobreña (Granada) en época medieval”, en Arqueología y Territorio. Revista Electrónica del programa de Doctorado, ISBN 1698-5664, n 4 , pp. 203-216.

Navas Rodríguez, J. y J. Mª García-Consuegra Flores, (2009), "La formación de una incipiente madina nazarí: la Salawbinya de los ss. XIV-XV" en Arqueología y Territorio. Revista Electrónica del programa de Doctorado, ISBN 1698-5664, nº 6, pp. 225-237.

Olivera Serrano, C. (1995), "Geografía y poblamiento", pp. 51, en Sismicidad histórica del Reino de Granada (1487-1531), Monografía no 12, Instituto Geográfico Nacional, Madrid, pp. 37-267.

Romero Martínez, A. (1995), "Construcción y reconstrucción de la fortaleza de Salobreña. Las cuentas de 1496-1498" en Cuadernos de Estudios Medievales y Ciencias y Técnicas Historiográficas, 20, pp. 117-141.

Vilar Sánchez, J. A. (2007), Los Reyes Católicos en la Alhambra, Granada, Apéndice documental, pp. 673-676. (Archivo General de Simancas, Guerra Antigua, legajo 1315, doc. 20, transcripción de Juan Antonio Vilar Sánchez). 